\title{
COMPLEX TREATMENT THE PATIENTS WITH PSORIASIS AND CONCOMITANT ACTIVATED HERPES VIRUS INFECTION, TYPES 1, 2
}

DOI: 10.36740/WLek202009213

\author{
Ulyana V. Fedorova, Orysya 0. Syzon, Marianna 0. Dashko, Iryna Ya. Voznyak \\ DANYLO HALYTSKY LVIV NATIONAL MEDICAL UNIVERSITY, LVIV, UKRAINE
}

\begin{abstract}
The aim: Is to increase effectiveness and assess safety of the antiviral therapy in complex treatment of patients with psoriasis with activated chronic herpes virus infection of types 1 and 2 .

Matherials and methods: 120 patients and 25 practically healthy persons were examined.

Results: It has been studied an effect of antiviral therapy on the background of basic therapy in patients with P+HSV 1,2: the percentage of HSV 1,2 DNA detection after the use of acyclovir and/or inosine pranobex was decreased in saliva from $22.0 \pm 3.43 \%$ to $6.7 \pm 1.32 \%(p<0.01)$ and in epithelium - from $33.3 \pm 4.23 \%$ to $6.7 \pm 1.8 \%$ ( $p<0.01$ ); The use of antiviral therapy has showed a decrease in the expression of miR 155 molecules from $126.3 \pm 10.5 \mathrm{U} / 6$ to $62.4 \pm 5.48 \mathrm{U} / 6$ ( $p<0.05$ ), an increase in the number of T-regulatory lymphocytes from $6.8 \pm 1.25 \%$ to $9.1 \pm 1.41 \%$ ( $p=0.0503$ ); a decrease of IFN-a level in saliva from $10.1 \pm 1.84 \mathrm{ng} / \mathrm{ml}$ to $8.2 \pm 1.27 \mathrm{ng} / \mathrm{ml}(\mathrm{p} 1=0.0398)$; in the serum IL-23 level was significantly decreased from $14.9 \pm 2.11 \mathrm{pg} / \mathrm{ml}$ to $8.8 \pm 2.03 \mathrm{pg} / \mathrm{ml}(\mathrm{p}<0.05)$ and TGF- $\beta$ synthesis was increased from $3.9 \pm 1.23 \mathrm{pg} / \mathrm{ml}$ to $9.3 \pm 2.21 \mathrm{pg} / \mathrm{ml}(\mathrm{p}<0.01)$. Conclusions: An improved method of treatment and evaluation of its clinical and immunological effectiveness based on an integral criterion was suggested as a result of conducted antiviral therapy amid basic therapy in patients with psoriasis with activated HSV-1 and HSV-2.
\end{abstract}

KEY WORDS: psoriasis, herpes simplex viruses, type 1 (HSV-1) and type 2, miR155, miR146a, antiviral therapy

Wiad Lek. 2020;73(9 p. II):1968-1972

\section{INTRODUCTION}

Nowadays, psoriasis (P) continues to be a common systemic pathology, both in adults (up to 10\%) and children (up to $4 \%$ ). It is often resistant to standard therapy, which has a negative impact on the psychological and emotional status of patients, reduces their ability to work and determines a relevant medical and social problem $[1,2,3]$. It is established that psoriasis is often associated with many infections, especially viral ones, which can actively influence the pathogenesis and clinical course of dermatosis and determine the effectiveness of treatment $[4,5]$.

Herpes simplex viruses, type 1 (HSV-1) and type 2 (HSV2 ), hold a special place among immunotropic opportunistic viruses. Their prevalence is particularly significant in the population: labial - from $67 \%$ to $92 \%$ and genital - from $25 \%$ to $64 \%[5,6]$. Nowadays, the consequences of the activation of chronic HSV-1 and HSV-2 infection, especially in the immunocompromised cohort of the population (up to $20 \%$ ) under the conditions of its activation, are not studied fully [6,7]. Psoriasis belongs to this group and is the basis of immune dysregulation, in which HSV-1 and HSV-2 infection can actively influence the course of the disease and determine effectiveness of its treatment.

Considering a powerful innovative development of both diagnostic and therapeutic biological technologies, the immunopathogenetic aspects of psoriasis with scientific and practical importance are studied actively $[8,9,10]$. Existing researches focused on these issues are often controversial [11]. An urgent task of modern dermatology is early detection of activation of HSV-1 and HSV-2 infection in patients with psoriasis and its relations with the clinical course of the disease, as well as establishment of criteria for assessing the levels of immunoregulatory disorders, which substantiates feasibility of antiviral drugs use in complex dermatosis therapy [12,13].

Thus, there is no structured complex and differentiated approach to the therapeutic tactics for managing patients with psoriasis with concomitant HSV-1 and HSV-2 infection. It confirms the feasibility of further study of molecular genetic and immunological mechanisms of disease development in order to develop effective therapeutic and prophylactic interventions for patients.

\section{THE AIM}

The aim of the study is to increase effectiveness and assess safety of the antiviral therapy in complex treatment of patients with psoriasis with activated chronic herpes virus infection of types 1 and 2, taking into account molecular genetic and immunological mechanisms of development of these diseases.

\section{MATHERIALS AND METHODS}

145 patients were examined using general clinical, general laboratory, biochemical, molecular genetics, immuno- 
logical and instrumental methods: 120 patients and 25 practically healthy persons. The following groups were identified: 25 healthy persons (1); 38 patients with $\mathrm{P}(2) ; 37$ patients with activated HSV 1,2 (3); 45 patients with $P$ and activated HSV $1,2(\mathrm{P}+\mathrm{HSV} 1,2)$ - the main group (4). To compare the effectiveness of the recommended treatment regimens, the patients of the main group were divided into 4 subgroups, taking into account the severity of HSV 1,2 and the use of different antiviral therapy during 3 months: 12 patient $(4 \mathrm{~A})$ - the use of basic therapy only (order of the Ministry of Healthcare of Ukraine No752 of 20/11/2015); 10 patients with mild $\mathrm{P}(4 \mathrm{~B})$ - antiviral treatment of inosine pranobex (IP) in dose $50 \mathrm{mg} / \mathrm{kg} /$ day with basic therapy; 13 patients with moderate and severe $\mathrm{P}(4 \mathrm{C})$ - the use of acyclovir (AC) with basic therapy in dose $1000 \mathrm{mg} /$ day and IP in dose $50 \mathrm{mg} / \mathrm{kg} / \mathrm{day} ; 10$ patients with moderate and severe P (4D) - the use of AC in dose $1000 \mathrm{mg}$ on the background of the basic therapy.

The clinical evaluation of patients has been performed based on the complaints, general examination, the Dermatology Life Quality Indexes for patients (DLQI) and the Psoriasis Area Severity Index (PASI) in psoriasis. To detect DNA of HSV 1,2 and miR molecules, the molecular-genetic method of polymerase chain reaction was used; in biological media, the level of cytokines, IgM and G to HSV1,2 was measured by enzyme immunoassay, phenotyping of lymphocytes and their activation markers - by flow cytometry method. Statistically obtained results were processed using a licensed program «Statistica 6.0».

\section{RESULTS AND DISCUSSION}

Psoriasis is often associated with many infections, especially viral ones (HSV1,2), which can actively influence the pathogenesis and clinical course of dermatosis and determine the effectiveness of treatment $[4,5,6,7]$.

In contrast to patients with $\mathrm{P}$, in patients with $\mathrm{P}+\mathrm{HSV} 1,2$, the lesions of the body upper part were more often observed: scalp - $71.2 \%$ vs $44.7 \%$ ( $p<0.05)$, face $-24.4 \%$ vs $7.9 \%(\mathrm{p}<0.05)$ and upper extremities $-43.3 \%$ vs $36.8 \%$ $(\mathrm{p}<0.05)$. Common $\mathrm{P}$ was found in the majority $(80.0 \%)$ of patients with $\mathrm{P}+\mathrm{HSV} 1,2$ compared to the group of patients with $\mathrm{P}$ alone $(65.8 \% ; \mathrm{p}<0.05)$, where the diffuse type of disease was predominated $(34.2 \%$; $<<0.05)$. The typical course of the disease was observed in all patients with $\mathrm{P}$ in contrast to the patients with P+HSV 1,2 (71,1 $\% ; \mathrm{p}<0.05)$, in whom the exudative $\mathrm{P}$ was found -17.8 $\%$ and Barber's limited pustular P - $11.1 \%$ cases. It has been found that in patients with P+HSV 1,2, there was dominated plaque $\mathrm{P}$ with mixed $(82.2 \%$; $\mathrm{p}<0.01)$, guttate with papules arranged in a ring-like configuration $(65.6 \%$; $\mathrm{p}<0.05)$, expressed $(51.1 \%$; $<<0.05)$ and sharply expressed $(28.9 \%)$ infiltration of rashes. Instead, in patients with only $\mathrm{P}$, there was dominated the winter $(81.6 \%$; $\mathrm{p}<0.01)$ type of disease with large plaque, diffuse plaque with a garland-like arrangement of rashes $(48.2 \%$; $<<0.05)$, moderate $(34.2 \%)$ and expressed degree of psoriatic plaques infiltration (57.8 \% patients). In patients with $\mathrm{P}$, there was observed a moderately recurrent process $(94.7 \pm 3.43 \%$; $<<0.01)$ of moderate severity $(62.8 \pm 3.04 \%$; $>0.05)$ in the progressive stage $(63.2 \pm 4.62 \% ; \mathrm{p}<0.05)$ of disease compared to the main group of patients. At the same time, in patients with P+HSV 1,2 on the background of the dominance of disease moderate severity dominance, there have also been found the severe $(31.1 \pm 2.74 \% ; \mathrm{p}<0.05)$ and very severe forms of $\mathrm{P}(6.7 \pm 2.34 \% ; \mathrm{p}<0.05)$, mainly in the stationary stage $(84.4 \pm 5.41 \% ; \mathrm{p}<0.05)$ with a frequently recurrent $(73.3 \pm 4.26 \% ; \mathrm{p}<0.05)$ course and the tendency to move into a continuously recurrent process. The nature of the psoriatic process was in direct expressed correlation dependence on the detection of viral load and the duration of the last disease exacerbation $(r=+0.6$ and $r=+0.7$, respectively). The frequency of relapses per year and the course of the last psoriasis exacerbation had a direct impact on the nature of the relapse.

In patients with $\mathrm{P}+\mathrm{HSV} 1,2$, index PASI was $20.2 \pm 1.46$ vs $12.3 \pm 1.75-$ in patients with $\mathrm{P}(\mathrm{p}<0.05)$. The analysis of the questionnaire for patients with HSV 1,2 has showed an expressed effect of the disease on the quality of life in 28 $(62.2 \%)$ patients (DLQI $=27.3 \pm 1.7$ points), compared to the patients with the only $\mathrm{P}$ in $18(47.3 \%$; $\mathrm{p}<0.05)$ patients.

We examined 37 patients with activated HSV 1,2 to compare the clinical course of $\mathrm{P}+\mathrm{HSV} 1,2$. In patients with $\mathrm{P}+\mathrm{HSV}$ 1,2, compared to patients with only activated HSV 1,2, there has been dominated the localization of psoriatic rashes often with a wet component, in the genital and intergluteal areas but with less crust formation $(70.0 \pm 2.62 \%$ vs $6.7 \pm 1.07 \% ; \mathrm{p}<0.01)$, higher frequency of crack formation ( $45.5 \pm 3.32 \%$ vs $61.1 \pm 4.29 \%$; $p<0.05)$ and more $-2-5$ relapses during the year $(67.6 \pm 8.06 \%$ vs $35.5 \pm 4.65 \% ; \mathrm{p}<0.05)$.

The results of the molecular-genetic studies in different biological media have showed that DNA of HSV 1,2 was not detected in patients with $\mathrm{P}$ and healthy persons. In patients with activated HSV 1,2, there has been found DNA of Herpes simplex virus infection in the blood $-8.3 \pm 2.34 \%$, in saliva $-12.5 \pm 3.28 \%$, in the epithelium $-29.2 \pm 4.54 \%$ cases. In patients with $\mathrm{P}+\mathrm{HSV} 1,2$, there have been diagnosed the slightly higher parameters of this virus in biological media, compared to the previous group: in saliva $-20.0 \pm 3.89 \%(\mathrm{p}<0.05)$, epithelium $-33.3 \pm 4.38 \%$ $(\mathrm{p}<0.05)$ patients, and in the blood - not found $(\mathrm{p}<0.001)$. In patients with $\mathrm{P}+\mathrm{HSV} 1,2$, compared to the patients with activated HSV 1,2, specific DNA was more often found in saliva -1.7 times and in epithelium - 2.3 times.

We observed an increased level of IgM to HSV 1,2 in patients with activated HSV $1,2(1.1 \pm 0.08 \mathrm{~g} / \mathrm{l} ; \mathrm{p}<0.05)$ and in patients with $\mathrm{P}+\mathrm{HSV} 1,2(0.6 \pm 0.09 \mathrm{~g} / \mathrm{l} ; \mathrm{p}<0.05)$, compared to the healthy persons and patients with only $\mathrm{P}$ $(0.3 \pm 0.48 \mathrm{~g} / \mathrm{l} ; \mathrm{p}<0.05)$. In patients with activated HSV 1,2 and patients with $\mathrm{P}+\mathrm{HSV} 1,2$, synthesis of specific $\operatorname{IgG}$ was significantly increased $(6.9 \pm 2.33 \mathrm{~g} / \mathrm{l} ; \mathrm{p}<0.001$ and $3.61 \pm 1.02$ $\mathrm{g} / \mathrm{l} ; \mathrm{p}<0.01)$, compared to the healthy persons and patients with only $\mathrm{P}(1.9 \pm 0.75 \mathrm{~g} / \mathrm{l} ; \mathrm{p}<0.05)$.

Increased expression of miR 155 has been detected in patients with $\mathrm{P}(98.3 \pm 9.92 \mathrm{U} / 6 ; \mathrm{p}<0.05)$, activated HSV 1,2 

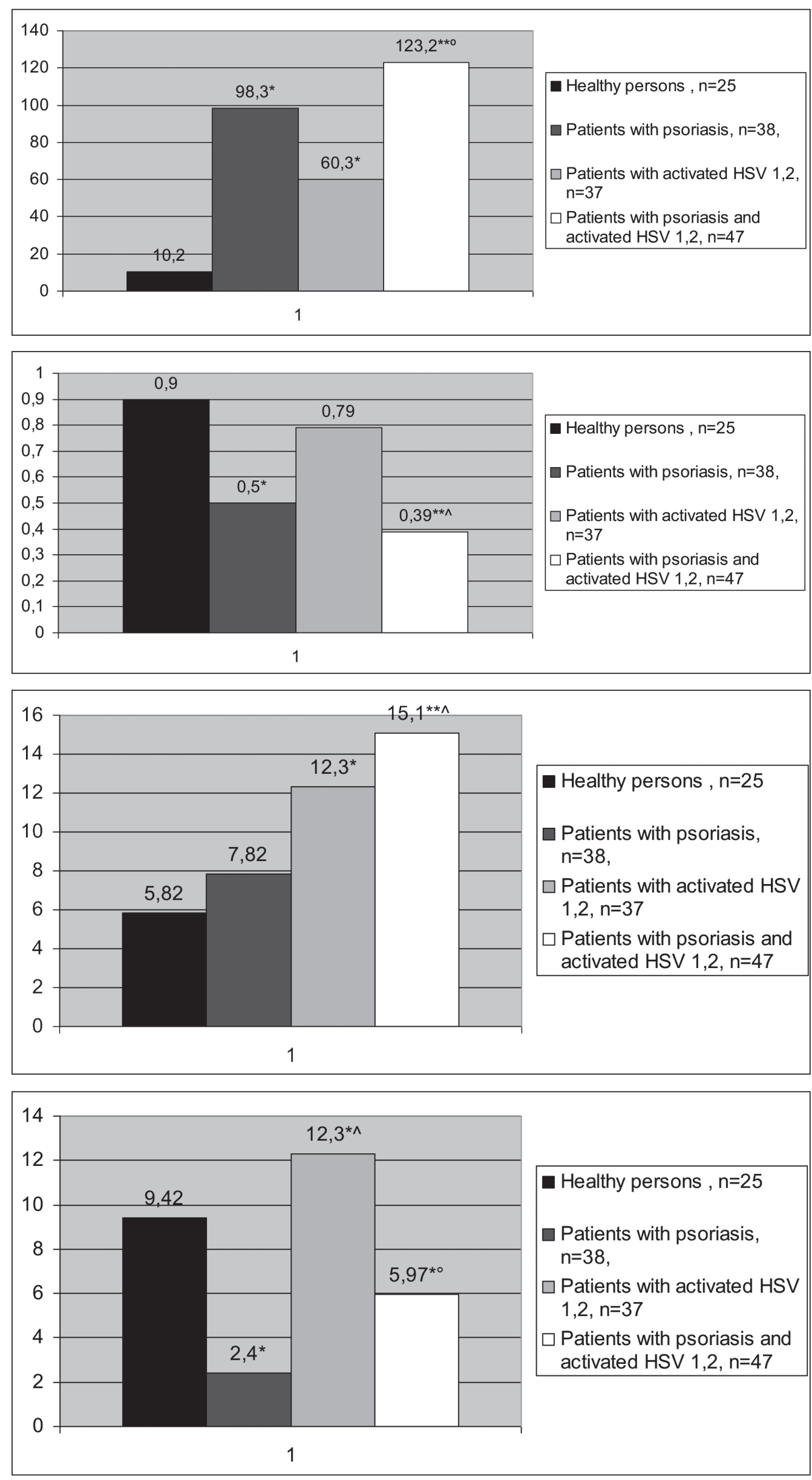

Note: * value of statistical difference with "healthy" group; ^ - value of statistical difference with the group "P"; ${ }^{\circ}$ - value of statistical difference with "HSV-1 and HSV-2" group

Figure 1. The expression level of miR 155 molecules $(\mathrm{U} / 6)$ in blood serum of the studied groups of patients and apparently healthy persons

Note: * - value of statistical difference with "healthy" group; ^ - value of statistical difference with the group " $\mathrm{P}$ "; ${ }^{\circ}$ - value of statistical difference with"HSV-1 and HSV-2" group

Figure 2. The expression level of miR 146a (U/6) molecules in blood serum of the studied groups of patients and apparently healthy persons

Note: * value of statistical difference with "healthy"group; ^ - value of statistical difference with the group " $\mathrm{P}$ "; ${ }^{\circ}$ - value of statistical difference with"HSV-1 AND HSV-2" group

Figure 3. Levels of interleukin-23 $(\mathrm{ng} / \mathrm{ml})$ in blood serum of the studied groups of patients and apparently healthy persons

Note: ${ }^{*}$ - value of statistical difference with "healthy"group; ^ - value of statistical difference with the group " $\mathrm{P} "{ }^{\prime}{ }^{\circ}$ - value of statistical difference with "HSV-1 AND HSV-2" group

Figure 4. Levels of transforming growth factor $\beta(\mathrm{ng} / \mathrm{ml})$ in blood serum of the studied groups of patients and apparently healthy persons 


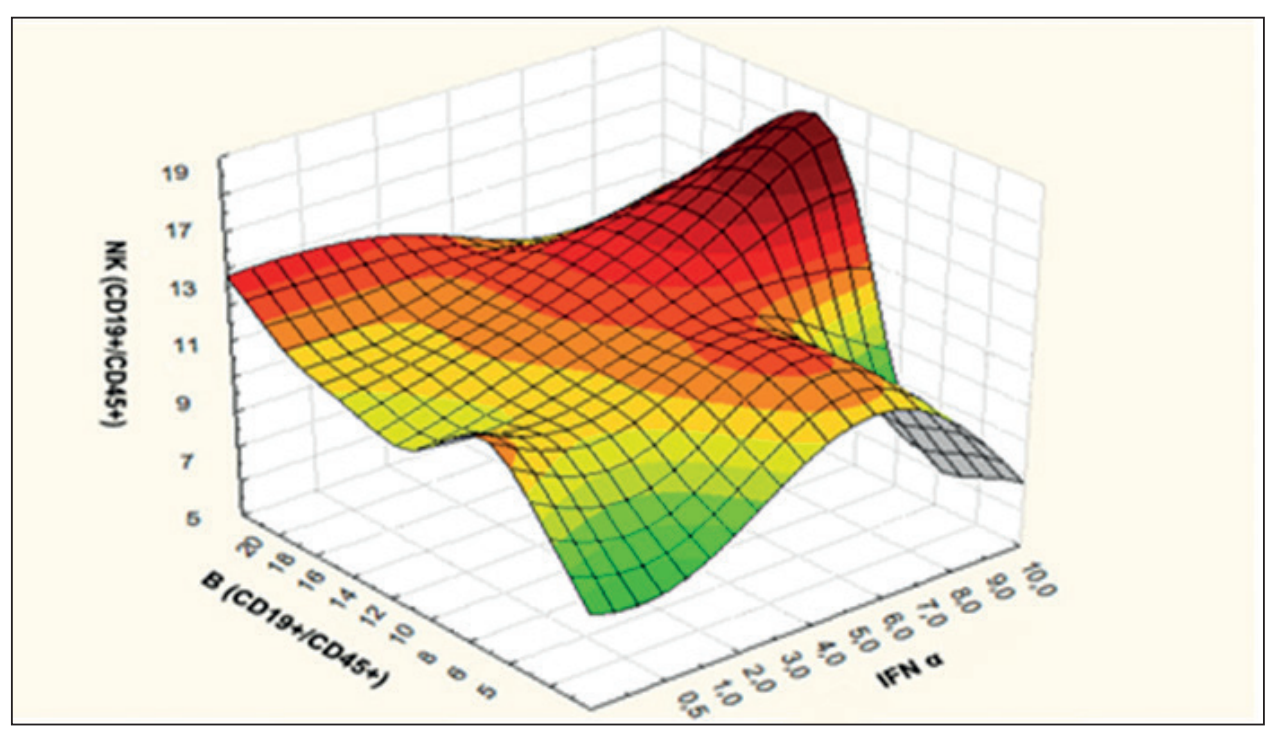

Figure 5. Multivariate analysis of relations between B-lymphocytes, NK cells, and level of interferon-a synthesis in blood serum of patients with psoriasis-activated HSV-1 and HSV-2 after antiviral and basic therapy
(60.3 \pm 7.32 U/6; $<<0.05)$, especially P+HSV 1,2 (123.2 \pm 8.42 $\mathrm{U} / 6 ; \mathrm{p}<0.01)$, compared to the healthy persons. At the same time, the synthesis of miR 146a was significantly reduced in patients with $\mathrm{P}+\mathrm{HSV} 1,2$, compared to the healthy persons $(0.4 \pm 0,06 \mathrm{U} / 6 ; \mathrm{p}<0.01)$ and patients with activated HSV 1,2 $(0.8 \pm 0.08 \mathrm{U} / 6 ; \mathrm{p}<0.05)$. The expression level of miR 155 molecules was higher 2.04 times and miR 146a molecules lower 1.80 times $(\mathrm{p}<0.05)$ in patients with $\mathrm{P}+\mathrm{HSV} 1,2$, compared to the group of patients with $P$.

It has been studied an effect of antiviral therapy on the background of basic therapy in patients with P+HSV 1,2: the percentage of HSV 1,2 DNA detection after the use of acyclovir and/or inosine pranobex was decreased in saliva from $22.0 \pm 3.43 \%$ to $6.7 \pm 1.32 \%(\mathrm{p}<0.01)$ and in epithelium - from $33.3 \pm 4.23 \%$ to $6.7 \pm 1.8 \%(\mathrm{p}<0.01)$; the Ig $\mathrm{M}$ level was decreased in subgroups of patients $(4 \mathrm{~B}+4 \mathrm{C})$ with inosine pranobex or combination with acyclovir $(\mathrm{p}<0.05)$. The use of antiviral drugs has reduced the number of patients with P+HSV 1,2 with replication of Herpes simplex virus infection in saliva - 4.9 times, in the epithelium - 3.3 times. IgG level was increased after basic treatment $(4 \mathrm{~A})$ to $4.8 \pm 1.32 \mathrm{~g} / \mathrm{l}(\mathrm{p}<0.05)$ and in patients after acyclovir with basic treatment (4D) to $3.5 \pm 0.92$ $\mathrm{g} / \mathrm{l}(\mathrm{p}<0.05)$ that can indicate further periodic replication of HSV 1,2 in these subgroups. In $4 \mathrm{~B}$ and $4 \mathrm{C}$ subgroups, the use of antiviral therapy has showed a decrease in the expression of miR 155 molecules from $126.3 \pm 10.5 \mathrm{U} / 6$ to $62.4 \pm 5.48 \mathrm{U} / 6(\mathrm{p}<0.05)$, while increasing the expression of miR $146 \mathrm{a}$ from $0.36 \pm 0.05 \mathrm{U} / 6$ to $0.7 \pm 0.08 \mathrm{U} / 6(\mathrm{p}<0.05)$ that also distinguished these patients from subgroup $4 \mathrm{~A}$ $(p<0.05)$. It has been found a direct correlation between lymphocyte counts and miR 155 molecule expression in the blood of patients treated with inosine pranobex and/ or acyclovir $(\mathrm{r}=0.46 ; \mathrm{p}<0.05)$. Various epigenetic effects alter the synthesis of miR molecules in the study groups, which is reflected in the activity of proinflammatory miR 155 and inhibitory miR 146a (Fig. 1-2).

By evaluating the features of blood lymphocytes phenotyping in the investigated patients, we have found: an increase in the number of T-helper cells $(44.2 \pm 2.47 \%$; $\mathrm{p}<0.01)$ and a decrease of regulatory T-lymphocytes $(4.2 \pm 1.08 \%$; $\mathrm{p}<0.05)$ in patients with $\mathrm{P}$ compared to healthy persons. The same relationships were observed in patients with P+HSV 1,2 (48.9 $\pm 3.99 \% ; p<0.01-6.9 \pm 1.30 \% ; p<0.05)$, respectively, compared to healthy persons but still this group had a higher number of regulatory T-lymphocytes, compared to patients with only $\mathrm{P}(\mathrm{p}<0.05)$.

In patients receiving combined antiviral therapy, an increase in the number of T-regulatory lymphocytes from $6.8 \pm 1.25 \%$ to $9.1 \pm 1.41 \%(\mathrm{p}=0.0503)$ has been found after treatment $(4 \mathrm{~B}+4 \mathrm{C})$, in contrast to patients receiving basic therapy $(4 \mathrm{~A})$, where was observed a decrease from $8.3 \pm 1.12 \%$ to $5.2 \pm 1.44 \%(\mathrm{p}=0.0496)$. After combined therapy in patients with $\mathrm{P}+\mathrm{HSV} 1,2$, the following relationships of average strength we have revealed: a direct relationship between B- lymphocytes and T-regulatory cells ( $r=0.41$; $\mathrm{p}<0.05$ ), inverse - between $\mathrm{T}$ - helper cells and $\mathrm{T}$ - cytotoxic lymphocytes $(r=-051 ; p<0.05)$, multifactorial - between $T$-, B- lymphocytes and activated T-lymphocyte population, confirming the balance of cellular immunological processes regulation in treated patients using of antiviral drugs.

It has been performed the comparison on activity of IFN- $\alpha$, IL-23 and TGF- $\beta$ synthesis in different biological fluids in the studied groups of patients. In patients with P, the level of IFN- $a$ synthesis - an important antiviral cytokine was lower than in patients with activated HSV $1,2(\mathrm{p}=0.0168)$ and in patients with $\mathrm{P}+\mathrm{HSV} 1,2(\mathrm{p}=0.0276)$. In patients with $\mathrm{P}+\mathrm{HSV} 1,2$, it has been found an increase of IFN- $\alpha$ synthesis in serum 3.5 times, compared to healthy persons and 2.8 times, compared to the patients with P. A key pro-inflammatory cytokine associated with the development of autoimmune skin inflammation is IL23 , whoselevel in patients with $\mathrm{P}$ was $12.3 \pm 2.81 \mathrm{ng} / \mathrm{ml}(\mathrm{p}<0.01)$ and in patients with $\mathrm{P}+\mathrm{HSV} 1,2-15.1 \pm 3.21 \mathrm{ng} / \mathrm{ml}(\mathrm{p}<0.001)$, compared to the practically healthy persons $(5.82 \pm 2.73 \mathrm{ng} / \mathrm{ml})$. It is important to note that patients with $\mathrm{P}+\mathrm{HSV} 1,2 \mathrm{had}$ the most powerful synthesis of IL-23 and its level was significantly different from the group of patients with activated HSV 1,2 $15.1 \pm 3.21 \mathrm{ng} / \mathrm{ml}$ vs $7.82 \pm 2.01 \mathrm{ng} / \mathrm{ml}(\mathrm{p}<0.05)$. In patients with $\mathrm{P}+\mathrm{HSV}$ 1,2, we observed an increase of IL-23 levels 2.6 times, compared to healthy persons, and 1.9 times, compared to the 
patients with activated HSV 1,2. A significant role in the regulation of the immune response belongs to TGF- $\beta$. In patients with $\mathrm{P}$ and $\mathrm{P}+\mathrm{HSV} 1,2$, the comparison of its synthesis has showed the differences from the synthesis in healthy persons $(\mathrm{p}<0.01$ and $\mathrm{p}<0.05$ ), respectively, with no significant difference between them. In patients with activated HSV 1,2, the synthesis of this cytokine was activated $-12.3 \pm 3.48 \mathrm{ng} / \mathrm{ml}$ but no significance, compared to healthy persons. In patients with $\mathrm{P}+\mathrm{HSV} 1,2$, we observed a decrease of serum TGF- $\beta$ synthesis -1.9 times, compared to healthy persons, and 2.1 times, compared to the patients with activated HSV 1,2 (Fig. 3-4).

In subgroups of patients with $\mathrm{P}+\mathrm{HSV} 1,2$ after combined antiviral treatment $(4 \mathrm{~B}+4 \mathrm{C})$, we observed a decrease of IFN- $\alpha$ level in saliva from $10.1 \pm 1.84 \mathrm{ng} / \mathrm{ml}$ to $8.2 \pm 1.27 \mathrm{ng} / \mathrm{ml}$ ( $\mathrm{p} 1=0.0398$ ) but its blood level was not significantly changed, although it was higher than in subgroup (4D) receiving basic therapy and acyclovir $(\mathrm{p}=0.0437)$. In the serum of these patients after complex treatment, IL-23 level was significantly decreased from14.9 $\pm 2.11 \mathrm{pg} / \mathrm{ml}$ to $8.8 \pm 2.03 \mathrm{pg} / \mathrm{ml}(\mathrm{p}<0.05)$ in contrast to the $4 \mathrm{D}(\mathrm{p}<0.05)$ and $4 \mathrm{~A}(\mathrm{p}<0.05)$ subgroups and TGF- $\beta$ synthesis was increased from $3.9 \pm 1.23 \mathrm{pg} / \mathrm{ml}$ to $9.3 \pm 2.21 \mathrm{pg} / \mathrm{ml}(\mathrm{p}<0.01)$, compared to the same subgroups. In patients from $4 \mathrm{~B}+4 \mathrm{C}$ subgroups, these therapeutic tactics has showed the restoration of the relationships between the number of B-lymphocytes, NK-cells and IFN- $\alpha$ synthesis in the blood serum (Fig.5).

It provides the use of Inosine pranobex and/or Acyclovir amid a standard therapy for 90 days depending on the severity of HSV-1 and HSV-2, which contributes to the improvement of clinical and immunological effectiveness and safety of treatment of such patients compared with patients receiving only basic therapy: "marked improvement" $39.1 \pm 3.4$ vs. $0 \%$, "improvement" - $56.5 \pm 3.15$ vs. $58.3 \pm 5.93 \%$, "no improvement" $-4.35 \pm 0.08 \%$ vs. $41.7 \pm 3.15 \%$.

\section{CONCLUSIONS}

An improved method of treatment and evaluation of its clinical and immunological effectiveness based on an integral criterion was suggested as a result of conducted antiviral therapy amid basic therapy in patients with psoriasis with activated HSV-1 and HSV-2.

\section{REFERENCES}

1. Cantarutti A., Donà D., Visentin F. et al. Epidemiology of frequently occurring skin diseases in Italian children from 2006 to 2012: a retrospective, Population-Based Study. Pediatr Dermatol. 2015; 32 (5): 668-678.

2. Coates L., Savage L., Emery P. Pathogenesis of psoriasis and psoriatic arthritis. In: Handbook of Psoriasis and Psoriatic Arthritis, eds. Warren R., Menter A. 2016: 7-16.

3. WhitlockS.M., Enos C.W., Armstrong A.W. et al. Management of psoriasis in patients with inflammatory bowel disease: From the Medical Board of the National Psoriasis Foundation. J Am Acad Dermatol 2018; 78:383.

4. Furue K., Ito T., Tsuji G. et al. Autoimmunity and autoimmune comorbidities in psoriasis. Immunology. 2018; 154(1): 21-27.

5. Boehncke W.H. Etiology and pathogenesis of psoriasis. Rheum Dis Clin North Am. 2015; 41 (4): 665-675.
6. Fedorova U., Syzon 0., Gajduchok I., et al. Clinical and metabolic analysis of disorders in psoriatic patients. Wiadomości Lekarskie. 2019; 72(7): 1304-1309.

7. Zeeshaan A., Abrar A., David B. et al. Tools for the Diagnosis of Herpes Simplex Virus 1/2: Systematic Review of Studies Published Between 2012 and 2018. JMIR Public Health Surveill . 2019: 5(2): e14216. . doi: 10.2196/14216.

8. Syzon 0., Dashko M., Fedorova U. Modern specific features and therapy of psoriasis and arthropathic psoriasis courses. Wiadomości Lekarskie. 2018; 71 (2/1): 322-325.

9. Voznyak I.Ya, Syzon 0.0.,Dashko M.0. Specific nature of changes in main immunohistochemical parameters of neoangiogenesis in patients with psoriasis. Wiadomości Lekarskie. 2018; 71 (3,pt.2): 658-662

10. Di Meglio P., Nestle F. Immunopathogenesis of Psoriasis In Clinical and Basic Immunodermatology. Springer Intern Publish. 2017; 1:.373-395.

11. Deng Y., Chang C., Lu Q. The inflammatory response in psoriasis: a comprehensive review. Clin Rev Allergy Immunol. 2016; 50 (3): P.377389.

12. Donigan J.M., PascoeV.L., Kimball A.B. Psoriasis and herpes simplex virus are highly stigmatizing compared with other common dermatologic conditions: A survey-based study. J Am Acad Dermatol. 2015; 73(3): 525-526.

13. Tobólska S., Terpiłowska S., Jaroszewski J., Siwicki A.K. Genotoxicity and mutagenicity of inosine pranobex. JVet Res. 2018; 62 (2): 207-213.

\section{Scietific research work}

State registration number: $0116 U 004506$

Cipher: IH. 25. 01.0001. 16

"Clinical and experimental justification of monitoring of diagnostics and standardized methods for treatment of metabolic disorders of internal organs and skin and their complications."

\section{ORCID and contributionship:}

Ulyana V. Fedorova: 0000-0002-7148-3754 A, B, C, D, E, F

Orysya O. Syzon: 0000-0002-7011-2521 A, D, E, F

Marianna O. Dashko: 0000-0001-6441-5326 C, D, E, F Iryna Ya Voznyak: 0000-0001-7735-4358 ${ }^{E, F}$

\section{Conflict of interest:}

The Authors declare no conflict of interest.

\section{CORRESPONDING AUTHOR Marianna 0. Dashko}

Danylo Halytsky Lviv National Medical University

1 Konovalets str., 79014 Lviv, Ukraine

tel: $+380677691977 ;+380504131489$

e-mail:mariannadashko@gmail.com

Received: 23.04 .2020

Accepted: 17.07 .2020

A - Work concept and design, B - Data collection and analysis, C - Responsibility for statistical analysis,

$\mathbf{D}$-Writing the article, $\mathbf{E}-$ Critical review, $\mathbf{F}-$ Final approval of the article 